\title{
KARAKTERISTIK MUTU IKAN SELAMA PENANGANAN PADA KAPAL KM. CAKALANG
}

\author{
Sitkun Deni \\ **Staf Pengajar FAPERTA UMMU-Ternate, e-mail: -
}

\begin{abstract}
ABSTRAK
Ikan merupakan komuditas yang muda dan cepat membusuk, sehingga ikan memerlukan penanganan yang cepat dan cermat, dalam upaya mempertahankan mutunya sejak ikan di angkat dari air. Penanganan ikan harus di lakukan secepat mungkin untuk menghindari kemunduran mutu ikan sehingga di butuhkan bahan dan media pendinginan yang sangat cepat dalam menurunkan suhu ikan pada pusat thermal ikan. Penelitian dilaksanakan untuk mempelajari karakteristik perubahan rnutu ikan selama proses penanganan oleh nelayan pada kapal pole and line dan mengetahui sejauh mana upaya penanganan dilaksanakan dengan cara mengikuti kegiatan penangkapan serta pengujian organoleptik terhadap sampel dengan menggunakan uji organoleptik dan uji kruskal-Walis. Hasil penelitian menunjukan bahwa secara umum penanganan yang dilakukan oleh nelayan sudah cukup baik walaupun belum sepenuhnya mengikuti standar penanganan yang dikeluarkan Direktorat Mutu dari Kementerian Kelautan dan Perikanan. Sifat fisik dari ikan yang tertangkap dengan alat tangkap pole and line sangat mudah rusak. Namun ikan hasil tangkapan sampai tiba di TPI tergolong dalam kategori ikan segar karena masih dalam standar ikan segar menurut SNI 01-2729-1992. Sanitasi dan higiene kurang diperhatikan dalam penanganan oleh nelayan baik sanitasi tempat penanganan maupun peralatan. Sedangkan higiene para nelayan masih kurang baik, terutama sifat-sifat buruk nelayan selama proses penanganan berlangsung dimana sambil bercanda, merokok, meludah dan bersin sembarangan..
\end{abstract}

Kata Kunci: KM. Cakalang, Mutu, Pole and Line

\section{PENDAHULUAN}

\subsection{Latar Belakang}

Sumberdaya laut yang dimiliki Provinsi Maluku Utara dengan luas laut terbesar tersebut sangat melimpah, dimana potensi perikanan laut Maluku Utara sebesar 1.035.230,00 ton/tahun dan potensi lestari yang dapat di manfaatkan setiap tahunnya di perkirakan $828.180,00$ ton/tahun. Sektor perikanan dan kelautan Maluku Utara merupakan sektor yang memiliki prospek yang cerah untuk di bangun menjadi suatu kekuatan ekonomi yang tangguh, strategis dan berkelanjutan. Pembangunan sektor ini sangat prospektif untuk di jadikan suatu pengembangan bisnis serta pengolahan dan pemasaran hasil perikanan di propivinsi
Maluku Utara, dimana diketahui umumnya produksi hasil perikanan di Maluku utara masih di dominasi oleh kegiatan perikanan tangkap, karna bahan baku ikan masih di peroleh dari hasil tangkapan laut dengan jumlah tangkapan pada tahun 2007 mencapai 30.000 ton (DKP Provinsi Maluku Utara 2010). Hasil tangkapan tersebut umumnya didominasi oleh ikan pelagis dengan persentasi sekitar 70 $\%$ dari total hasil tangkapan laut, yang kemudian dari jumlah hasil tangkapan ikan pelagis tersebut lebih didominasi oleh ikan pelagis besar di antaranya dari marga scrombidae yang terdiri dari ikan tuna, cakalang dan ikan tongkol.

Penangkapan jenis ikan pelagis besar yang terdiri dari ikan tuna, cakalang dan 


\section{सत्ती है}
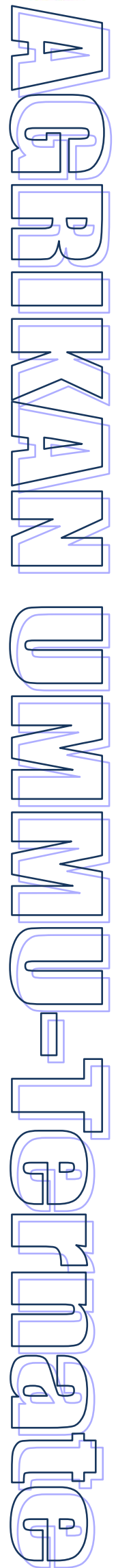

tongkol umumnya lebih didomiasi oleh kapal pole and line sebagai kapal yang spesifikasinya ditujukan khusus untuk menangkap ketiga jenis ikan tersebut. Kapal pole and line merupakan jenis kapal yang beroperasi dengan menggunakan alat tangkap kail yang dilengkapi dengan joran sebagai pengganti main linenya. Kapal pole and line memiliki areal penangkapan yang agak jauh dari fishing base sehingga harus dilengkapi dengan perlengkapan yang dapat dimanfaatkan sebagai sarana dan prasarana yang dikhusunya untuk dapat menjaga mutu hasil tangkapan agar tidak mengalami penurunan mutu.

Ikan merupakan komuditas yang muda dan cepat membusuk, sehingga ikan memerlukan penanganan yang cepat dan cermat, dalam upaya mempertahankan mutunya sejak ikan di angkat dari air. Pendinginan merupakan perlakuan yang paling umum dalam mempertahankan mutu hasil perikanan terutama dalam tahap penanganan. Dalam penanganan ikan segar di upayakan suhu tetap rendah mendekati $0^{\circ} \mathrm{C}$. Penanganan ikan harus di lakukan secepat mungkin untuk menghindari kemunduran mutu ikan sehingga di butuhkan bahan dan media pendinginan yang sangat cepat dalam menurunkan suhu ikan pada pusat thermal ikan. Tingkat kesegaran ikan akan semakin cepat menurun atau ikan akan mudah menjadi busuk pada suhu tinggi dan sebaliknya pembusukanan dapat di hambat suhu rendah (Suparno et al, 1993).

Dengan melihat bahwa proses penangkapan jenis ikan pelagis besar diantaranya tuna, cakalang dan tongkol merupakan jenis ikan yang cepat mengalami penurunan mutu sehingga diperlukan proses penanganan yang lebih dikapal, dimana dilihat dari pendapat Moeljanto (1992), bahwa ikan dan perikanan lainnya merupakan bahan pangan yang muda mengalami pembusukanan (high perishable food) paska mortem, hal ini diakibatkan oleh temperatur yang tinggi pada daerah tropis seperti Indonesia mengakibatkan kemunduran mutu cepat terjadi hanya dalam hitungan waktu 8 jam setelah ikan di tangkap dan di daratkan, dan juga penyebab utama pembusukan adalah kegiatan mikro organisme yang berasal dari tubuh ikan itu sendiri (bakteri dan enzim) dan faktor luar (kontaminasi dan oksidasi) yang dapat terjadi secara bersamaan.

Saat ini sebagian besar produksi ikan di Indonesia dihasilkan oleh usaha perikanan rakyat berskala kecil yang masih terbatas baik fasilitas, teknologi digunakan di perairan Morotai, purse seine merupakan alat tangkap yang dominan. Sementara itu nelayan setempat, banyak yang melakukan penangkapan tanpa menggunakan persiapan peralatan dan bahan unluk menyimpan hasil tangkapan dengan baik. Hal ini sering terjadi, baik pada nelayan yang rnelakukan penangkapan dengan one day fishing, maupun yang tidak. Menurut Yunizal dan Wibowo(199S), ternyata ikan yang ditangkap dengan kapal nelayan tanpa dilengkapi sarana penyimpanan yang baik, 20 $30 \%$ mengalami kerusakan sebelum ikan sampai ke darat. Kondisi seperti ini mengakibatkan hasil tangkapan ikan nelayan tidak optimal, Dengan tingkat kesegaran pasca panen ikan kurang baik, kerusakan atau kehilangan (losses) selama penanganan dan pengolahan tidak dapat dihindari.

\subsection{Tujuan dan manfaat}

Penelitian ini bertujuan untuk:

1) Mempelajari karakteristik perubahan rnutu ikan selama proses penanganan oleh nelayan dengan menggunakan pole and line serta tingkat kerusakan (losses) pasca panen.

2) Mengetahui sejauh mana upaya penanganan (handling) di kapal. Penelitian ini diharapkan dapat menambah bahan infomrasi kepada penelitit, dinas terkait serta para pelaku ekonomi dibidang perikanan.

\section{METODE PENELITIAN}

\subsection{Waktu dan Tempat}

Penelitian ini di laksanakan selama bulan Agustus - September 2014 bertempat di kapal KM. Cakalang yang beroperasi di Kabupaten Pulau Morotai dengan fisihing base berada di desa Daruba.

\subsection{Alat dan Bahan}

Alat dan bahan yang digunakan dalam penelitian ini adalah box styroform, plastik pembungkus untuk pengemasan ikan dan 

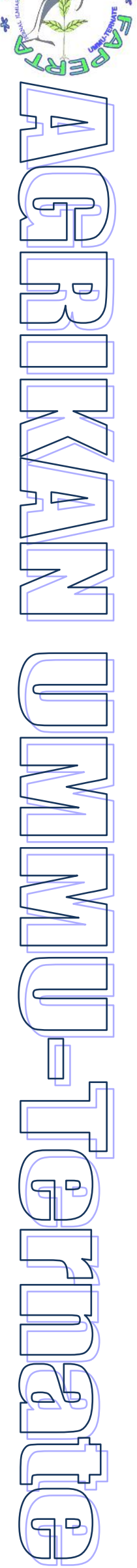

thermometer untuk mengukur suhu. Sedangkan bahan yang digunakan adalag ikan hasil tangkapan, es balok serta alat tulis menulis.

\subsection{Metode Kerja}

Turunnya mutu ikan yang dijual dipasar umumnya disebabkan oleh proses penanganan mulai dari kapal penangkap sampai pada pendaratan ikan di tempat pendaratan ikan yang tidak sesuai dengan standar penanganan yang telah ditetap oleh Ditjen Mutu dari Departement Kelautan dan Perikanan. Pengamatan yang dilakukan pada penelitian ini, meliputi uji organoleptik pada saat ikan baru ditangkap sampai pada pendaratan di Tempat Pendaratan Ikan (TPI). Sampel yang akan diuji pada setiap titik penagmatan diambil dari dua contoh dan segera dimasukkan kedalam Styrofoam yang berisi es.

\subsection{Uji Organoleptik}

Metode yang digunakan untuk uji organoleptic adalah dengan score sheet berdasar SNI-01-2345-1991. Pengujian organoleptic merupakan cara pengujian yang bersifat subjektif dengan menggunakan indera yang ditujukan pada penampakan, bau, konsistensi dari dan perut. Data yang diperoleh diuji dengan rancangan acak lengkap dan uji lanjut yang dipakai adalah uji beda nyata terkecil (BNT).

\subsection{Analisis Data}

Untuk mengetahui hubungan antara tahapan proses penanganan ikan dan besarnya nilai organoleptik yang menentukan tingkat kesegaran ikan menggunakan statistik non parametric dengan metode uji Kruskal Wallis dan uji lanjut Multiple Comparison, dengan rumus sebagai berikut (Steel dan Tome, 1989):

$$
\begin{gathered}
H=\frac{12}{n(n+1)} x \frac{\sum R i^{2}}{n i}-3(n+1) \\
H^{\prime}=\frac{H}{\text { Pembagi }} \\
\text { Pembagi }=1-\frac{\sum T}{(n-1) n(n+1)}, \sum T \\
=(t-1) t(t+1)
\end{gathered}
$$

Keterangan :

$$
\mathrm{H}=\text { Ni1ai Uji Kruskal-Wallis }
$$$$
\text { n }=\text { Jumlah total data }
$$

$$
\begin{aligned}
& \text { ni } \text { Banyaknya pengamatan dalam } \\
& \text { perlakuan ke-i }
\end{aligned}
$$
dilanjutkan dengan uji lanjut Multiple Comparison (Walpole, 1975) dengan rumus :

$$
|R i-R j|<Z \alpha / 2 p \sqrt{\frac{(N+1) k}{6}}
$$

Keterangan :

$$
\begin{aligned}
\mathrm{Ri}= & \text { Rata-rata rangking dalam perlakuan } \\
& \text { ke-i } \\
\mathrm{Rj}= & \text { Rata-rata dalam Perlakuan ke } \mathrm{j} \\
\mathrm{N}= & \text { Banyaknya data }
\end{aligned}
$$

\section{HASIL DAN PEMBAHASAN}

3.1. Operasi Penangkapan

Penangkapan dengan huhate (pole and line) biasanya di tujukan untuk menangkap cakalang (Katsuwonus pelamis), metode yang di gunakan dalam menangkap cakalang yaitu melihat langsung atau mencari gerombolan ikan dengan teropong, dengan memperhatikan tanda-tanda:

1. Adanya kelompok-kelompok burung laut (camar) yang sedang menyambar-nyambar permukaan air laut

2. Adanya buih-buih yang muncul secara tibatiba akibat adanya gerombolan ikan yang sedang bermain pada permukaan laut.

3. Benda besar (batang kayu) yang hanyut, hal ini sangat memungkinkan adanya gerombolan ikan yang turut berlindung di bawahnya.

4. Adanya ikan-ikan kecil yang berlompatlompat di permukaan air laut.

5. Adanya ikan paus, lumba-lumba, di mana ikan cakalang berenang bersama-sama ikan tersebut.

Pengintaian ini di lakukan oleh nahkoda dan di bantu oleh awak kapal yang mengintai dari atas deck kapal, dengan berpatokan pada tanda-tanda di atas. Apabila tanda-tanda tersebut di atas telah kelihatan maka kapal pole and line bergerak menuju tanda-tanda di atas. Setelah di perkirakan bahwa jarak antara kapal dengan gerombolan ikan cukup dekat $\pm 20 \mathrm{~m}$, maka posisi kapal terhadap gerombolan ikan, adalah : 
a. Kapal harus memotong arah renang ikan pada lambung kiri kapal.

b. Arah angin dari bagian buritan kapal sehingga memudahkan pelemparan umpan, penyemprotan air dapat berfungsi penuh serta memudahkan proses pemancingan.

c. Sebaiknya posisi kapal membelakangi matahari.

Setelah jarak dan posisi kapal dengan gerombolan ikan sudah tepat, maka mulailah umpan di lemparkan kearah gerombolan ikan, pada saat itu kapal mulai bergerak dengan kecepatan 1-2 knot dan para pemancing mulailah menurunkan alat pancingnya.

Pemancingan di lakukan dengan setiap kali melemparkan ikan umpan hidup sebagai perangsang agar ikan cakalang lebih mendekat ke kapal sehingga mudah terjangkau oleh pancing-pancing. Pemancing-pemancing cakalang umumnya mempunyai ketrampilan khusus.Kegiatan pemancingan di lakukan begitu rupa yaitu dengan menjatuhkan pancing ke atas permukaan air dan bila di sambar oleh ikan cakalang dengan cepat di angkat melalui atas kepaladan secara otomatis terlempar ke dalam deck kapal.Kegiatan ini di lakukan berulang-ulang dalam tempo yang sangat singkat. Pemancingan semacam ini lebih di kenal dengan cara banting di samping itu ada di sebut cara gepe yaitu cara pemancingan dengan pole and line di mana setelah ikan terkena pancing dan di angkat dari dalam air kemudian pengambilannya dari mata pancing di lakukan dengan cara menjepit ikan di antara tangan dan badan pemancing.

\subsection{Hasil Tangkapan}

Jenis ikan yang menjadi tujuan penangkapan dengan alat tangkap pole and line yaitu ikan cakalang (Katsuwonus Pelamis), Madidihang (Thunus Albacares) dan Tongkol (Euthynnus Afinnis). Ikan cakalang yang di tangkap selama operasi penangkapan selama penelitian adalah ikan dengan ukuran panjang 15-35 cm, dengan berat rata-rata $1,5-3 \mathrm{~kg}$, tertangkap pada daerah 2-4 mil laut dari darat. Ikan madidihang yang tertangkap selama operasi penangkapan pada saat penelitian adalah ikan dengan ukuran panjang $15-30 \mathrm{~cm}$, dengan berat 1,5- $3 \mathrm{~kg}$, tertangkap pada daerah 2-4 mil laut dari daratan. Ikan tongkol yang tertangkap selama operasi penangkapan pada waktu penelitian adalah ikan dengan ukuran panjang $15-20 \mathrm{~cm}$, dengan berat rata-rata $0,5-2$ $\mathrm{kg}$, tertangkap pada daerah 2-4 mil laut dari daratan.

\subsection{Penanganan Hasil Tangkapan}

Cara penanganan dalam pendinginan ikan dengan es sangat beragam tergantung pada tempatnya (kapal penangkap, tempat pendaratan ikan, tempat pelelangan, pasar ikan, pabrik pengolahan ikan, supermarket, dan lainlain), jenis ikan, dan tujuan pendinginan. Tetapi secara umum dapat di gariskan bahwa es harus di campurkan dengan ikan sedemikian rupa hingga setiap permukaan ikan bersinggungan dengan es, pendinginan berlansung jika es bersinggungan dengan ikan. Makin banyak permukaan ikan yang bersinggungan dengan es, maka pendinginan akan berlansung lebih cepat sehingga pembusukan dapat segera di hambat. Pekerjaan-pekerjaan yang di perlukan, sedapat mungkin di lakukan pada tempat yang dingin, atau sekurang-kurangnya di tempat teduh agar sinar matahari tidak dapat memanaskan ikan secara lansung. Faktor yang tidak kalah pentingnya dalam prosedur pendinginan ikan adalah kecepatan. Semua pekerjaan harus di lakukan dengan cepat agar suhu ikan dapat segera di turunkan. Alur Proses penanganan ikan hasil tangkapan yang dilakuan di kapal KM. Cakalang seperti terlihat pada Gambar 1 .

$$
\text { Penanganan hasil tangkapan }
$$

merupakan suatu tugas yang harus di selesaikan dengan cepat oleh seluruh anak buah kapal setelah selesai melakukan operasi penangkapan. Penanganan ikan hasil tangkapan dengan baik akan menentukan mutu atau kualitas ikan tersebut sehingga harga ikan pun akan menjadi tinggi. Langkahlangkah yang perlu di ambil dalam melakukan proses penanganan di atas kapal KM. Cakalang (Gambar 1) dapat dijelaskan sebagai barikut :

\subsubsection{Tahap Sortir}

Setelah selesai operasi penangkapan di adakan pengsortiran. Dalam tahap ini di lakukan pemisahan ikan sesuai dengan ukuran sebelum di masukan ke dalam bak penampung, tujuan dari penyortiran yaitu memisahkan menurut kualitas yakni apabila terdapat luka 
सहते

pada tubuh ikan maka dipisahkan dan tidak
layak lagi diproses lebih lanjut. Menurut
Mueljanto (1992), proses penyortiran atau
pemisahan hasil tangkapan harus sesuai
dengan standar HACCP yaitu dapat dilihat dari
beberapa aspek sebagai berikut:
$\begin{aligned} & \text { 1. Hasil tangkapan atau ikan dipisahkan sesuai } \\ & \text { dengan jenis dan ukuran, ikan yang } \\ & \text { mengalami luka dipisahkan dan tidak } \\ & \text { diproses, karena ikan yang mengalami luka } \\ & \text { akan mempercepat proses kontaminasi } \\ & \text { bakteri dan dapat merembet hasil tangkapan } \\ & \text { lainnya. }\end{aligned}$

2. Point kritis dalam tahapan proses sortir ini yang dikontrol adalah hasil tangkapan ikan yang luka dan memar fisiknya dihindarkan. 3.3.2. Tahap Pencucian

Tahap ini di lakukan untuk membersihkan ikan dari darah serta kotoran yang menempel pada tubuh ikan tujuan tahap ini yaitu untuk mengurangi jumlah bakteri yang terdapat pada tubuh ikan sehingga mutu ikan dapat terjaga. Pencucuian umumnya dilakukan dengan menggunakan air laut sebelum diletakan pada bak yang berisi es curai.
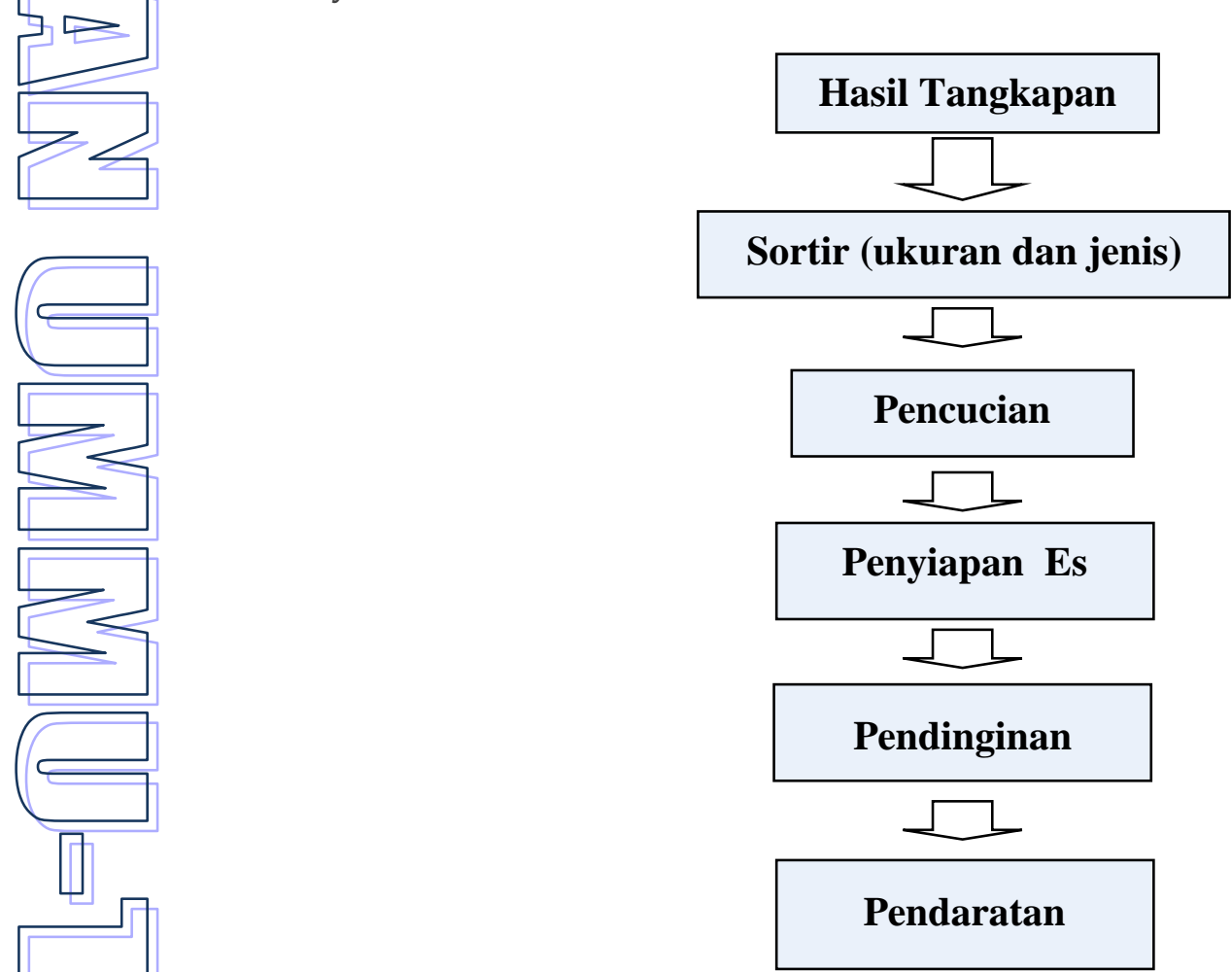

Gambar 1. Proses Penanganan Hasil Tangkapan pada Kapal Pole and Line

\subsubsection{Penyiapan Es}

Es balok yang berada pada palka di keluarkan dan di masukan ke dalam karung untuk di hancurkan sampai ukuran yang paling besar berdiameter 5 $\mathrm{cm}$, tetapi rata-rata berdiameter $2-3 \mathrm{~cm}$, es berfungsi untuk mengurangi pertumbuhan bakteri dan menjaga agar suhu tubuh ikan tetap stabil sehingga pertumbuhan bakteri sangat sedikit sehingga mutu ikan dapat terjaga. Makin kecil ukuran es, makin banyak permukaan ikan yang bersinggungan dengan es, sehingga pendinginan berlansung lebih cepat (Hadiwiyoto, 1993).

\subsubsection{Tahap Pendinginan}

Setelah es di siapkan maka pendinginan lansung di mulai dengan cara mencampur ikan dengan es ialah dengan membuat lapisan es pada dasar, kemudian di atasnya di letakkan selapis ikan. Berikutnya, di buat lapisan es dan ikan berganti-ganti, dan di tutup dengan lapisan es sebagai lapisan teratas. Ikan tidak boleh menyinggung dinding wadah, antara ikan dan wadah harus di beri es. 

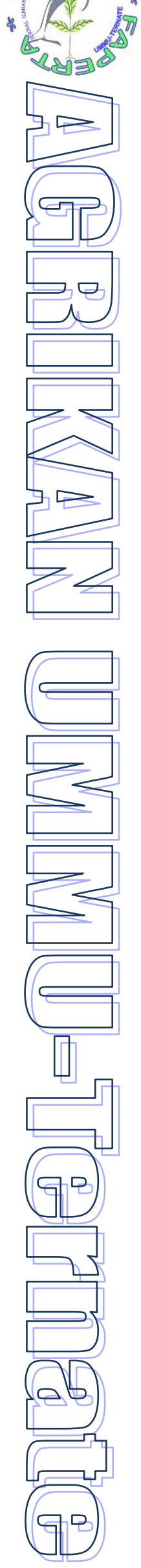

\subsection{Sanitasi dan Higiene}

Kebersihan dalam penanganan ikan mempunyai beberapa pengertian, antara lain membuang sumber pembusukan ikan (iendir, darah, insang, isi perut), mencuci bersih ikan dari kemungkinan pencemaran atau kontaminasi (Ilyas, 1983). Sanitasi dan higiene rnemegang peranan penting dalam penanganan ikan. Padahal sebagian besar nelayan menggunakan perahu sebagai tempat tinggal sehingga seluruh aktivitasnya pun dilakukan di atas perahu. Bagian dari perahu terbuat dari kayu, sehingga sulit dibersihkan jika kotor selama proses penanganan berlangsung (sanitasi dan higiene sukar dilakukan).

Sarana fisik yang digunakan selama proses penanganan ikan adalah ember, keranjang plastik dan box styrofoam. Tetapi, kebersihan peralatan terscbut kurang diperhatikan, peralatan tersebut setelah digunakan hanya dicuci dengan air laut, disikat tanpa sabun dan tanpa penyemprotan. Sebaiknya peralatan dicuci dengan menggunakan air bersih dengan cara disemprotkan dan disikat dengan sabun. Karena kotoran yang melekat pada alat-alat tersebut tidak akan terbuang semua. Air laut yang digunakan niungkin dapat menjadi sumber kontaminan. Air yang berhubungan dengan penanganan atau industri pengolahan pangan, harus memenuhi standar mutu yang diperlukan untuk air minum (Buckle et al, 1985).

Higiene para nelayan dapat dilihat dari pakaian dan kebiasaan nelayan ketika sedang bekerja. Pakaian yang dipakai jarang dicuci dan diganti, karena sulitnya mendapatkan air bersih. Para nelayan ketika bekerja sering merokok, meludah, buang air kecil atau besar di alas kapal dan bersin sembarang tempat. Kebiasaan jelek ini seharusnya dihilangkan, karena akan memperburuk keadaan sanitasi proses penanganan ikan. Kebersihan dalam penanganan ikan mempunyai beberapa pengertian, antara lain membuang sumber pembusukan dari ikan seperti lendir, darah, insang dan isi perut kemudian mencuci bersih ikan, cepat menurunkan suhu dengan pendinginan serta melindungi ikan dari kemungkinan pencemaran atau kontaminasi. Program higiene harus meliputi semua orang yang terlibat di dalam penanganan ikan. Untuk itu semua fasilitas kebersihan harus disediakan untuk mereka. Kondisi karyawan atau pekerja yang kotor dapat menyebabkan ikan terkofitaminasi dengan kotoran (Ilyas,1983).

\subsection{Penggunaan Es}

Untuk mendapatkan ikan yang mempunyai kesegaran baik, perlu diperhatikan jumlah es yang digunakan dan lamanya pengesan. Banyaknya es yang digunakan atau rasio antara banyaknya es dan banyaknya ikan yang didinginkan merupakan faktor yang menentukan. Hal ini menyangkut suhu ikan yang ingin dicapai. Jika rasionya kecil, suhu yang dicapai tidak cukup rendah untuk tetap mempertahankan kesegaran ikan dalam waklu yang lama. Sebaliknya jika rasionya terlalu besar akan dapat menyebabkan ikan rusak secara fisik karena himpitan dan tekanan oleh bongkahan atau pecahan es yang digunakan. Pada prinsipnya es yang ditambahkan harus dapat menurunkan suhu ikan sampai $0^{\circ} \mathrm{C}$, kemudian mempertahankan suhu tersebut selama penyirnpanan (Hadiwiyoto, 1993). Perbandingan yang baik untuk memperpanjang kesegaran ikan adalah 1 : 1 (1 $\mathrm{kg}$ es digunakan untuk mendinginkan $1 \mathrm{~kg}$ 
ikan) (Moeljanto, 1992). Berdasarkan Ditjen Mutu Departemen Kelautan dan Perikanan tentang standar penanganan ikan laut segar di atas kapal, bahwa perbandingan ikan dan es, untuk jenis palka tanpa lapisan insulasi dengan permukaan dari kayu, yaitu 1 : 1,5. Es yang digunakan dibeli sekitar 10 jam sebelum berangkat dan langsung diletakkan ke dalam palkah atau box styrofoam, tanpa dicuci dan dihancurkan terlebih dahulu. Es yang dibeli dari pedagang, dalam bentuk balok berukuran $60 \times 25 \times 25$ dengan berat sekitar $20 \mathrm{~kg}$. Dalam pengesan ikan, sebaiknya digunakan hancuran es yang terbuat dari air bersih atau es curah supaya himpitan alau tekanan pada ikan dapat dikurangi. Hancuran es yang digunakan harus dapat menutupi seluruh ikan yang didinginkan. Cara pemberian es hanya pada bagian atas permukaan ikan, akan menghasilkan produk yang kurang baik karena distribusi suhunya tidak merata. Jika jumlah ikannya banyak, pemberian hancuran es dilakukan dengan cara menyusun ikan dan es bergantian, sehingga terbentuk lapisan-lapisan antara es dan ikan. Lapisan yang terbawah dan teratas adalah lapisan es. Sisa es sebelumnya terkadang dipakai kembali apabila masih mencukupi, padahal es bekas tidak boleh digunakan lagi untuk tujuan ini. Pendinginan ikan dapat pula dilakukan dengan air laut yang direfrigrasikan sehingga dengan usaha pendinginan tersebut suhu ikan dapat mencapai sekitar 0" C (Hadiwiyoto, 1993).

\subsection{Perubahan Nilai Organoleptik}

Parameter atau kriteria untuk menentukan kesegaran ikan dapat dilakukan, salah satunya, dengan penentuan nilai organoleptik. Cara organoleptik adalah cara cepat, murah dan praktis untuk dikerjakan, tetapi ketelitiannya sangat tergantung pada tingkat kepandaian orang yang melaksanakannya. Penentuan secara organoleptik adalah dengan melihat penampakan luar, kelenturan daging ikan, keadaan mata, warna insang dan bau ikan. Untuk menetapkan kemunduran mutu ikan secara subjekrif (organoleptik) ini dapat dilakukan dengan menggunakan score sheet yang telah ditetapkan oleh Badan Standardisasi Nasional dengan SNI-01-234 5-1991. Pengujian organoleplik pada penelitian ini hanya tertuju pada mata, mulut dan tubuh ikan. Nilai yang digunakan 1 sampai dengan 10, karena ada kemungkinan ikan yang dinilai masih hidup (skor 10).

Tabel 1. Nilai Rata-Rata Organoleptik Hasil Tangkapan

\begin{tabular}{ccc}
\hline No & Perlakuan & Nilai Rata-Rata Organoleptik \\
\hline 1 & $\mathrm{~A}_{0}$ & 9.74 \\
2 & $\mathrm{~A}_{1}$ & 8.91 \\
3 & $\mathrm{~A}_{2}$ & 8.51 \\
4 & $\mathrm{~A}_{3}$ & 8.34 \\
\hline
\end{tabular}

Nilai raia-rata organoleptik hasil tangkapan pada setiap titik pengamatan mengalami penurunan (Tabel 1). Untuk hasil tangkapan saat $\mathrm{A}_{0}$ (ikan ditangkap) 9.74 dan saat A1 (ikan di dalam palkah) 8.91. Kondisi pada kedua tempat tersebut diperoleh ikan yang kesegarannya masih baik sekali (prima), dengan nilai organoleptik ikan yang rata-rata 9 saat $A_{0}$ dan saat $A_{1}$ dengan nilai organoleptik ikan yang rata-rata hampir mendekati 9 (pada titik A1). Nilai kesegaran yang tinggi, disebabkan ikan baru saja ditangkap dan baru mengalami kematian. Semua organ tubuhnya baik daging, mata, maupun insangnya masih benar-benar dalam keadaan segar. Dalam uji organoleptik, ikan pada kondisi ini berada pada nilai 9 yaitu dengan mata cerah, bola mata menonjol, kornea jernih, insang berwarna merah dan jernih, sayatan daging cemerlang (SN1-01 -2345-1991).

Saat A2 (ikan dibongkar) dan saat $\mathrm{A}_{3}$ (ikan sampai di TPI) ikan hasil tangkapan dengan berjalannya waktu dan proses penanganan terus mengalami penurunan masing-masing dengan nilai rata-rata organoleptik untuk ikan hasil tangkapan 8,51 (A2) dan 8,34 ( $\left.\mathrm{A}_{3}\right)$. Saat $\mathrm{A}_{2}$ dan $\mathrm{A}_{3}$, ikan masih dalam keadaan segar namun tidak sesegar seperti pada kondisi pertama (A0 dan $\left.A_{1}\right)$.

Penilaian secara organoleptik ikan yang mempunyai nilai antara 7 dan 8 , yaitu dengan bola mata agak cerah, kornea agak keruh, wama 
सहते
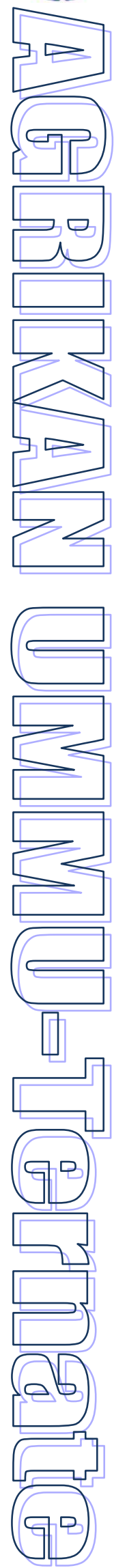

insang agak kusam, warna daging masih cemerlang namun agak lunak bila ditekan digolongkan ke dalam ikan yang memiliki tingkat kesegaran yang masih baik (advance) (Hadiwiyoto, 1993). Kondisi ikan dengan nilai organoleptik 9 adalah ikan yang bara saja tertangkap dan baru mati, sedangkan kondisi ikan dengan nilai organoleptik 7 (akhir masa rigor mortis) adalah bola mata agak cerah dan rata, sedikit lendir, sayatan daging cemerlang,
Berdasarkan Tabel 2, penurunan mutu yang paling tinggi terlihat pada titik pengamatan ikan hasil tangkapan pada titik pengamatan $\mathrm{A}_{0}$ ke $\mathrm{A}_{1}$ sebesar 8,55 \%. Waktu dari $A_{1}$ sampai ke $A_{2}$ lebih lama, yaitu 5-6 jam dibandingkan pada titik pengamatan $A_{0}$ ke $A_{1}$ dan $\mathrm{A}_{2}$ ke $\mathrm{A}_{3}$ yang waktunya lebih cepat (kurang dari 2 jam). Ikan hasil tangkapan karena diletakkan dalam palkah sehingga tidak menyebabkan penurunan yang besar pada $\mathrm{A}_{1}$ ke $A_{3}$, tetapi penurunan terbesar pada $A_{0}$ ke $A_{1}$, warna asli, sedikit ada pemerahan pada tulang belakang, perut agak lembek, bau netral, agak lunak, elastis bila ditekan dengan jari, sulit menyobek daging dari tulang belakang (SNI01-2345-1991). Ikan dinyatakan segar secara organoleptik jika waraa ikan mengkilap sesuai jenisnya, kelenturan dagingnya elastis, pupil hitam dan menonjol, waraa insang merah cerah dan bau segar spesifik sesuai dengan jenisnya (Yunizal dan Wibowo, 199B).

Tabel 2. Tingkat Penurunan Mutu Kesegaran Ikan Hasil Tangkapan

\begin{tabular}{ccc}
\hline No & Perlakuan & Nilai Rata-Rata Organoleptik \\
\hline 1 & A$_{0}$ sampai A1 & $8.55 \%$ \\
2 & A $_{1}$ sampai A & $4.49 \%$ \\
3 & A $_{2}$ sampai A & $1.96 \%$ \\
4 & A $_{3}$ sampai A & $14.37 \%$ \\
\hline
\end{tabular}

hal ini terjadi karena pada perlakuan Ao ikan baru saja mengalami kematian.

Gambar 2. disajikan histogram penurunan mutu kesegaran dalam persentase. Dari histogram terlihat bahwa penurunan mutu kesegaran ikan hasil tangkapan berkisar antara $1,96 \%$ sampai $14,37 \%$. Hal ini berarti persentase kemunduran mutu ikan sejak ikan ditangkap sampai pada TPI (nilai mutu organoleptik ikan 7) kurang dari $30 \%$.

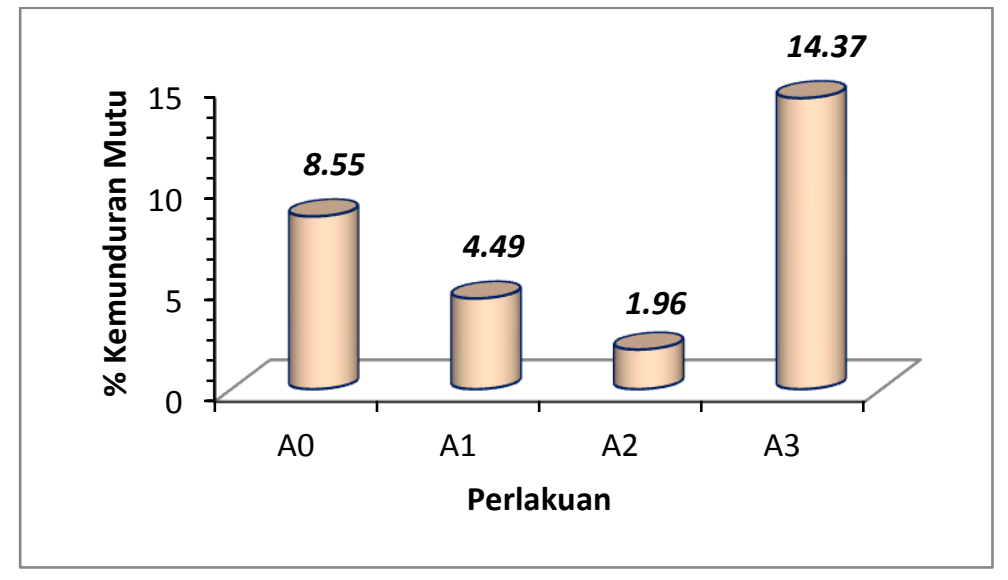

Gambar 2. Histogram Tingkat Penurunan Mutu Kesegaran Ikan

Dilihat dari nilai organoleptik ikan yang diamati dan hasil analisis ragam setelah dilakukan uji dengan menggunakan Kruskal Wallis, didapatkan untuk pada masing-masing tempat $\left(A_{0}, A_{1}, A_{2}, A_{4}\right)$ berbeda nyata antara satu dengan yang lainnya. Dengan demikian, penanganan pada masing-masing titik pengamatan tersebut terdapat perbedaan terhadap nilai organoleptik. Setelah dilakukan uji lanjut Multiple Comparison, ditunjukkan bahwa antar titik pengamatan berbeda secara signifikan terhadap nilai organoleptik ikan hasil tangkapan. Artinya penanganan yang dilakukan di atas kapal oleh nelayan untuk ikan hasil tangkapandengan pemberian es memberikan pengaruh yang nyata terhadap 
सहते
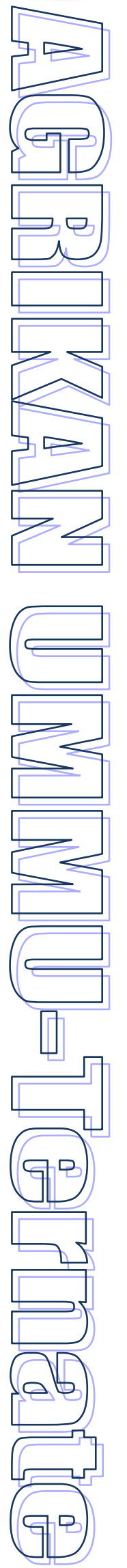

perubahan nilai organoleptik pada setiap titik pengamatan.

\section{PENUTUP}

4.1. Kesimpulan

Berdasarkan hasil penelitian dapat disimpulkan bahwa :

1. Secara umum penanganan yang dilakukan oleh nelayan sudah cukup walaupun belum sepenuhnya mengikuti standar penanganan yang dikeluarkan Direktorat Mutu dari Departemen Perikanan dan Kelautan. Sifat fisik dari ikan yang tertangkap dengan alat tangkap pole and line sangat mudah rusak. Namun ikan hasil tangkapan sampai tiba di TPI tergolong dalam kategori ikan segar karena masih dalam standar ikan segar menurut SNI 01 -2729-1992.

2. Sanitasi dan higiene kurang diperhatikan dalam penanganan oleh nelayan baik sanitasi tempat penanganan maupun peralatan. Sedangkan higiene para nelayan masih kurang baik, terutama sifat-sifat buruk nelayan selama proses penanganan berlangsung dimana sambil bercanda, merokok, meludah dan bersin sembarangan.

\subsection{Saran}

Perlu dilakukan pelatihan tentang sanitasi dan higienis kepada nelayan sehingga mutu ikan dapat dipertahankan lebih lama lagi serta perlu dilakukan penelitian lanjutan untuk melihat tingkat kerusakan secara mikrobiologi

\section{DAFTAR PUSTAKA}

Ayodhya, M.Sc, 1972. Kapal-kapal perikanan. Institut pertanian bogor.

Anugerah, N. 2007.Laut nusantara.Penerbit bumi aksara, Jakarta.

Astawan, I. 2007. Penanganan dan pengolahan hasil perikanan.Universitas terbuka, Jakarta.

Dirjen perikanan RI, 1979.Pedoman pengenalan sumber perikanan laut bagian I (jenis-jenis ikan ekonomi penting).Dirjen perikanan, departemen pertanian, Jakarta.

DKP Propinsi Maluku Utara, 2010. Laporan tahunan 2007.Dinas kelautan dan perikanan propinsi Maluku utara.

Djalal \& Dahuri, R, 2001.Menggali potensi kelautan dan perikanan dalam rangka pemulihan ekonomi menuju bangsa yang maju, makmur dan berkeadilan. Pidato dalam temu akbar CIVA-FPIK-IPB. Tanggal 25 agustus 2001. Bogor.

Direktorat pendidikan menengah kejuruan, 1982.Teori bangunan kapal 1.Departemen pendidikan dan kebudayaan. Jakarta.

Iskandar, B. H dan Y. Novita, 1997.Penentun praktikum kapal perikanan. Jurusan pemanfaatan sumber daya perikanan fakultas perikanan institut pertanian bogor. Bogor.

Kepadatan gerombolan ikan, kondisi meteorology, dan lain sebagainya (Mukhtar A. Pi, M.Si).

Murniyati,A. S dan Sunarman, 2000. Pendinginan,pembekuan dan pengawetan ikan. Kanisius. Jogjakarta.

Pasaribu, B. P dan M. Imron, 1990.Desain dan konstruksi kapal penangkap ikan untuk perairan laut dalam di perairan timur Indonesia.Fakultas perikanan.IPB Bogor.

Puristiwady P, 2006. Ikan-ikan laut ekonomis penting di Indonesia, LIPI Pres, Jakarta.

Subani, W. 1982.Penangkapan dengan pole and line.LPPL.No. 24. Jakarta. 